I.A. Tagaev ${ }^{1}$, S.U. Tursunova ${ }^{1}$, L.S. Andriyko ${ }^{2}$

\title{
INVESTIGATION AND SELECTION OF INITIAL MATERIALS AS POSSIBLE SOURCES FOR OBTAINING SORBENTS
}

\author{
${ }^{1}$ Navoi State Mining Institute \\ 170 Galaba Ave., Navoi, 210100, Uzbekistan \\ ${ }^{2}$ Chuiko Institute of Surface Chemistry of National Academy of Sciences of Ukraine \\ 17 General Naumov Str., Kyiv, 03164, Ukraine, E-mail: andriykolyuda@gmail.com
}

\begin{abstract}
The information about selection of initial materials based on bentonite, brown coal and technical soot for obtaining new sorbents is presented in this article. Obtaining new efficient carbon sorbents based on local Angren brown coals, a study on their colloidal-chemical and adsorption properties, as well as the search for new areas of their effective practical application for the purification of industrial sewage from the chemical and metallurgical industries are great scientific and practical interest and are highly relevant. The creation of sorbents with such properties is associated with a large energy expenditure, which is performed using special equipment for heat treatment of the material. Thus, the aim of the study was both of finding ways not only to reduce the cost of production of activated carbons with the involvement of materials based on local raw materials, but also to reuse them with subsequent regeneration. To achieve this, preliminary studies of determinition the points of temperature differences during thermal decarbonization and activation of the initial materials - Angren coal, soot from shop N. 6 of Navoiazot JSC and bentonite from the Navbakhor deposit were carried out by thermogravimetric methods. It was found that the main optimal ratio of bentonite/coal was $1 / 2$ at the temperature of $950{ }^{\circ} \mathrm{C}$ for 45 min, and the decarbonization degree of $19 \%$. The optimum parameter for burning out organic compounds in the soot composition is a temperature range from 520 to $1080{ }^{\circ} \mathrm{C}$, where the maximum carbon burning out to $75 \%$ is observed. Increasing the temperature of the sorbent heating to $700-1000{ }^{\circ} \mathrm{C}$ promotes the restructuring of the secondary structure of carbon of sorbate, stabilizes its properties, which simplifies its reactivation, especially in cases of a sorbate with a complex variable composition. The possibility of compatibility of the burning out parameters of two different types of compounds - Angren coal and bentonite from the Navbakhor deposit-is shown in order to obtain new hybrid types of sorbents that can be used for sewage treatment of industrial enterprises with their recycling usage in closed mode.
\end{abstract}

Keywords: carbon adsorbents, Angren brown coal, technical soot, bentonite, thermogravimetric analysis

\section{INTRODUCTION}

Nowadays carbon adsorbents have found wide application in various branches of the national economy - sewage water treatment of metallurgical, oil and gas, chemical, biochemical industries, hydrometallurgy, water treatment, oil and gas production and others [1-3]. In connection with the growing need in the Republic Uzbekistan for various types of sorbents, it is expedient to produce them on the basis of local raw materials, which become extremely important for the purpose of import substitution.

Thus, obtaining new efficient carbon sorbents based on local Angren brown coals, a study of their colloidal-chemical and adsorption properties, as well as the search for new areas of their effective practical application for the purification of industrial sewage from the chemical and metallurgical industries are of great scientific and practical interest and are highly relevant

The Republic of Uzbekistan is a state with developed chemical, oil and gas and mining and metallurgical industries. Recently, a large-scale reconstruction and modernization of these branches are being carried out. Due to this an increase in the output of finished export-oriented products is expected. At the same time, for the production of a large amount of products of the above-mentioned branches of industrial production, an even higher consumption of chemically finely purified water will be required. For fine water purification, mainly sorbing materials are used, which are imported from abroad with the use of foreign currency. In the mining and metallurgical industry sorbing materials for purification of technological waters 
and sorption of precious metals are also purchased for currency.

The creation of sorbents is associated with a large energy expenditure, which is performed using special equipment for heat treatment of the material. Therefore, it is necessary to select materials with low realizable value. For example, according to the analysis of the World Bank, the cost of coal in the US in 2016 was equal to $58 \$ / t$, in $2017-55 \$ / t$ ( $\$ 55=447645$ soums). In 2018 , the cost of coal is expected to grow. Currently in the Republic of Uzbekistan, the cost of one ton of coal is about 156.6 thousand soums/ton [4-5]. According to those prices, the cost of the sorbent produced from activated carbon in Uzbekistan can be quite low.

For industrial usage and purification of industrial process water from heavy metal ions, clay alumino silicate minerals such as bentonite clays (montmorillonite), kaolinite, biotite, vermiculite, attapulgite (palygorskite), glauconite are considered to be the most effective sorbents. Prospectivity of their using is linked, firstly, with the availability and cheapness of raw materials, and secondly, with sufficiently high performance properties: purification of water, prevent mechanical action, can take any form without the use of mechanisms, detain not only toxins, but also moisture, at rest they are liquefied, become denser during the use [6].

The analysis of works devoted to the production of activated carbon adsorbents and their application for wastewater treatment from dissolved inorganic salts has shown that the issues of cleaning industrial effluents by activated carbons are widely covered in the literature [7-13]. In this the determining role is given to the micropores of activated coals. However, at the present time, wastewater treatment by the ion exchange method is becoming increasingly widespread, since this method allows us to utilize valuable impurities and purify water up to the MPC standard. Therefore, it is proposed in the literature to activate the coals by oxidizing them in order to impart ion-exchange properties to them. But, the costs of oxidizing active carbons further increase their cost and reduce the profitability of their using for purification of process and waste water. [14-16].

In Uzbekistan, there are the largest deposits of natural sorbents in the form of coal and bentonite. To produce activated carbon, hightemperature muffle furnaces are used with a large amount of electricity. Therefore, for effective usage of them, the produced sorbents should be able to be repeatedly used in technological processes with their subsequent regeneration and to have the high strength. Leading scientific institutions of the Republic are engaged in research on the creation of sorption materials. The performed researches has shown that for repeated application, sorbents must be in the form of granules or tablets having high strength properties for subsequent extraction from the process, regeneration and further using.

Thus, the purpose of the study was the need to find ways not only to reduce the cost of production of activated carbons with the involvement of materials based on local raw materials, but also to reuse them with subsequent regeneration. To achieve this, preliminary studies of determinition the points of temperature differences during thermal decarbonization and activation of the initial materials - Angren coal, soot from shop No. 6 of Navoiazot JSC and bentonite from the Navbakhor deposit were carried out by thermogravimetric analysis.

Thermal analysis is a method for studying chemical and physico-chemical processes occurring in a substance under conditions of a temperature changing [17]. One of its functions is to determine the amount of evaporated structural water and hydroxides in minerals. In addition, the method makes it possible to determine the structure of thin water films in the composition of a mineral, including coal. It is based on the combination of differential thermal analysis with physical or physico-chemical methods, for example with thermogravimetry, dilatometry, mass spectrometry and emanationthermal analysis. Along with the transformations of matter that occur under the impact of the thermal effect, a change in the mass of the sample (liquid or solid) is recorded. Determination of the content of functional substances in an unknown sample is reduced to a definition of the endothermic peak area with the subsequent determination of the functional substance content by the standard curve constructed for the derivatograph. Each stage can be characterized by kinetic parameters determined by the data of the thermogravimetric analysis. Decomposition of the sample occurs with the release of a vapor-gas mixture. During 
the most intensive releasing of volatile substances, the pressure of the gas mixture inside the sample and directly above it can be significantly higher than atmospheric pressure. In many cases, the transformations are also associated with a change in the mass of the sample, which can be determined by the thermogravimetric method (TG) with great accuracy [11].

\section{EXPERIMENTAL PART}

Bentonite from the Navbakhor deposit intended for boreholes, a fine dust fraction of the coal from the Angren deposit and soot from the pyrolysis stage of methane of shop No. 6 of Navoiazot JSC were used as a binder for the preparation of granular activated sorbent.

The Navbakhor deposit was discovered in 1998. For extraction and processing, a plant was built with an annual capacity of 40.000 tons of finished products. Basically the contain of bentonite clays is represented by carbonatepalygorskite clays having a common chemical composition: $\mathrm{Mg}_{2} \mathrm{Al}_{2}\left[\mathrm{Si}_{8} \mathrm{O}_{20}\right](\mathrm{OH})_{2} \cdot 8 \mathrm{H}_{2} \mathrm{O} \cdot \mathrm{CaCO}_{3}$ (Tables 1-2) [18].

Table 1. Chemical composition of bentonite clays [18]

\begin{tabular}{lcccccccccccc}
\hline \multicolumn{1}{c}{ Name } & $\mathbf{S i O}_{2}$ & $\mathrm{TiO}_{2}$ & $\mathbf{A l}_{2} \mathbf{O}_{3}$ & $\mathrm{Fe}_{2} \mathbf{O}_{3}$ & $\mathbf{M g O}$ & $\mathbf{C a O}$ & $\mathbf{N a}_{2} \mathbf{O}$ & $\mathbf{K}_{2} \mathbf{O}$ & $\mathbf{P}_{2} \mathbf{O}_{5}$ & $\mathbf{S O}_{3}$ & $\mathbf{F e O}$ & $\mathbf{P O I}^{*}$ \\
\hline $\begin{array}{l}\text { Alkaline earth } \\
\text { clay }\end{array}$ & 56.23 & 0.61 & 13.56 & 6.50 & 3.76 & 0.69 & 0.98 & 2.20 & 0.92 & 0.49 & - & 14.06 \\
$\begin{array}{l}\text { Carbonate- } \\
\text { palygorskite } \\
\text { clay }\end{array}$ & 46.79 & - & 8.63 & - & 2.74 & 10.08 & - & 1.60 & 1.99 & - & 3.41 & 24.33 \\
\hline
\end{tabular}

*POI-percentage of other impurities

Table 2. Technical parameters of bentonite clay powder [18]

\begin{tabular}{|c|c|c|c|c|c|c|c|c|}
\hline Brand & $\begin{array}{l}\text { Density } \\
\mathrm{g} / \mathrm{cm}^{3}\end{array}$ & $\begin{array}{c}\text { Slurry } \\
\text { yield, } \mathbf{m}^{3} / g\end{array}$ & $\begin{array}{c}\text { Viscosity } \\
\text { c }\end{array}$ & $\begin{array}{l}\text { Filtration, } \\
\mathrm{cm}^{3} / 30 \mathrm{~min}\end{array}$ & $\begin{array}{c}\text { Thickness } \\
\text { of crust, } \\
\text { mm }\end{array}$ & $\begin{array}{c}\text { Content of } \\
\text { sand, \% }\end{array}$ & $\begin{array}{c}\text { Moisture, } \\
\%\end{array}$ & pH \\
\hline PBMB & 1.036 & 16 & 25 & 15.0 & 2.0 & 5 & $6-10$ & 9.5 \\
\hline PBG & 1.08 & 8 & 25 & 18 & 2.0 & 5 & $6-10$ & 7 \\
\hline PPD & 1.17 & 4 & 25 & 40 & 2.3 & 4.5 & $6-10$ & 8 \\
\hline
\end{tabular}

Table 3. Chemical composition of coal [2]

\begin{tabular}{ccccccccccc}
\hline & $\begin{array}{c}\text { Specific } \\
\text { gravity, } \\
\text { g/cm }\end{array}$ & $\mathbf{C}$ & $\mathbf{O}$ & $\mathbf{H}$ & $\mathbf{N}$ & $\mathbf{S}$ & $\begin{array}{c}\text { Volatile } \\
\text { substances }\end{array}$ & Moisture & Ash \\
\cline { 3 - 10 } & $1.2-1.5$ & $55-95$ & $5-15$ & $1.5-5.7$ & $0-1.5$ & $0.5-4$ & $45-2$ & $4-14$ & $2-45$ \\
\hline Amount & & & & & & & & & &
\end{tabular}

The main characteristics that determine the quality of coal are humidity, heat of combustion, sulfur, ash and volatile substance contents. The grade of coal is determined by the size of the piece and brand. There are more than 14 technological brands of coal. Ash is formed by coal burning.

Traditionally, the process of production of activated coals consists of the following stages: pyrolysis (carbonization) and activation.
Carbonization and activation is carried out in furnaces under the influence of high temperatures, without access of air.

The dominant position among these methods is vapor-gas activation one, which is based on the treatment of carbonizate with superheated water vapor. Steam preparation is carried out in a heat (steam-) generator, followed by activation of the coal. Schematically this process is described as interaction [19]: 


$$
\begin{gathered}
\mathrm{C}_{\text {carb }}+\mathrm{H}_{2} \mathrm{O} \rightarrow \mathrm{C}_{\mathrm{act}}+\mathrm{CO}_{2}(\mathrm{CO})+\mathrm{H}_{2} \\
\left(\mathrm{CO}+\mathrm{H}_{2} \mathrm{O} \rightarrow \mathrm{CO}_{2}+\mathrm{H}_{2}+\mathrm{Q}\right) .
\end{gathered}
$$

Soot after methane pyrolysis of shop N. 6 of JSC «Navoiyazot» is considered to be pure technical carbon. However, chemical analysis of the soot has shown its high ash content up to $6 \%$. Apparently, there are calcium and magnesium ions in the soot composition, which got into it at the methane extinguishing stage.

Thermogravimetric analysis of coal, soot and bentonite are performed by using a derivatograph Labsys ${ }^{\mathrm{TM}}$ Evo, developed to ensure ease of use and to obtain reliable and high performance indicators. The device is adapted for appliance in laboratories conducting research and quality control. Devices of the series Labsys ${ }^{\mathrm{TM}}$ Evo have a structure including: i) thermogravimetric balance (TG) connected to converters ATD and DSC; ii) metal-resistor furnace; iii) have multi-tasking software, managing various modules. The processes of decarbonization and activation of the obtained samples are performed in the muffle furnace of the brand DAIHAN Scientific User Manual (Version: 2.2.1) with a maximum firing index of $1200^{\circ} \mathrm{C}$, equipped with sensor timers for recording the firing time and an index of temperature set.

\section{RESULTS AND DISCUSSION}

Coal is a mineral deposit formed from the remains of ancient plants and animals underground without access to oxygen. Mainly the coal consists of high molecular weight aromatic compounds. The structure of the coal is shown in Fig. 1. As can be seen from Fig. 1 that coal is an organic hydrocarbon substance that has undergone a slow decomposition under the influence of biological processes.

The process of coal formation takes place under anaerobic conditions. In such conditions organic substances first form peat, and then fossil coals. The primary peat deposit consists of a mass of plant tissues. Under aerobic conditions, when plant residues were exposed to enriched with oxygen waters or a contact with the atmosphere, complete oxidation (decomposition) of the organic compound took place, with the release of carbon dioxide and light hydrocarbons, without peat formation. The peat transformation into the fossil coal is called incarbonization.

This process is accompanied by an increase in the carbon concentration and a decrease in the content of the three main carbon-forming elements - oxygen, nitrogen and hydrogen. The main factors of incarbonisation are temperature, pressure and time.

For obtaining of bentonite-coal sorbents, a fine coal fraction of Angren coal was used, which refers to the brand of lean coal, where the content of volatile substances is $12 \%$, and carbon up to $90 \%$ according to the classification shown in Table 4 [19].

Sorbents (from Latin sorbens - absorbing) solids or liquids that selectively absorb (sorbing) gases, vapors or dissolved substances from the environment. Depending on the nature of the sorption, absorbents are differentiated - material that form a solid or liquid solution with the absorbed substance. Absorbents are materials that absorb (thickening) a substance on their (usually highly developed) surface, and chemical absorbers that bind the absorbed substance, chemically interacting with it. Ion-exchange sorbents (ionites) is a separate group that absorbs ions of the same type from solutions with the release into the solution of an equivalent quantity of different type of ions. Activated carbon, silica gel, aluminum oxide, silicon dioxide, various ion-exchange resins, dibutyl phthalate and others are widely used to obtain such types of sorbents. [20-22].

Table 4. Classification of different types of coals [19]

\begin{tabular}{ccccc}
\hline Type of coal & Literal notation & $\begin{array}{c}\text { Volatile } \\
\text { substances, } \%\end{array}$ & $\begin{array}{c}\text { Carbon } \\
\text { content, } \%\end{array}$ & High heat value, kcal/kg \\
\hline Brown & B & 41 and more & 76 and more & $6900-7500$ \\
Candle* & C* & 39 and more & 76 & $7500-8000$ \\
Gas & G & 36 & 83 & $7900-8600$ \\
Fatty & F & 30 & 86 & $8300-8700$ \\
Coking & C & 20 & 88 & $8400-8700$ \\
Low-coking & LC & 15 & 89 & $8450-8780$ \\
Lean & L & 12 & 90 & $7300-8750$ \\
Anthracite & A & less than 8 & 91 and more & $8100-8750$ \\
\hline
\end{tabular}




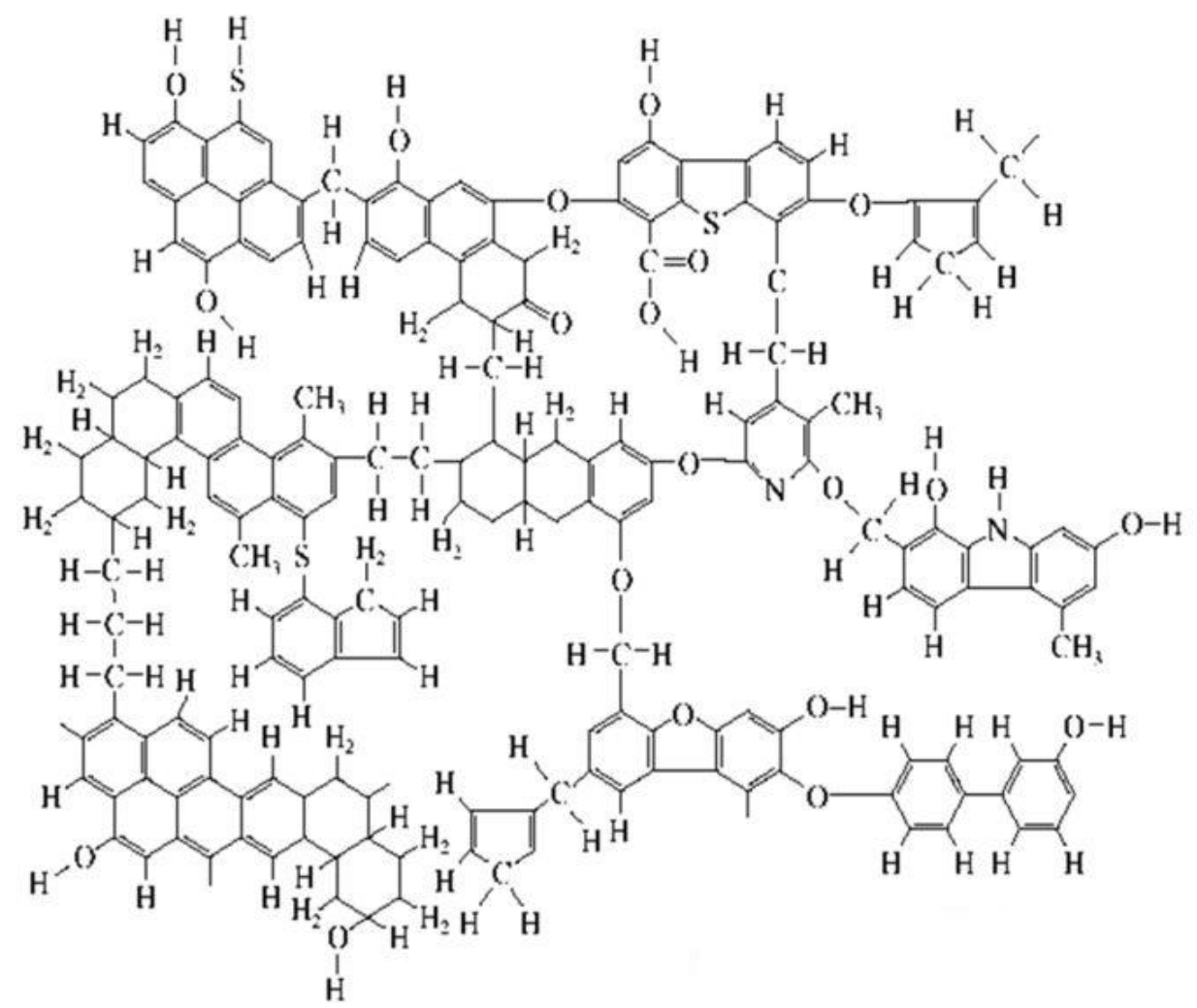

Fig. 1. The structure of coal [20]

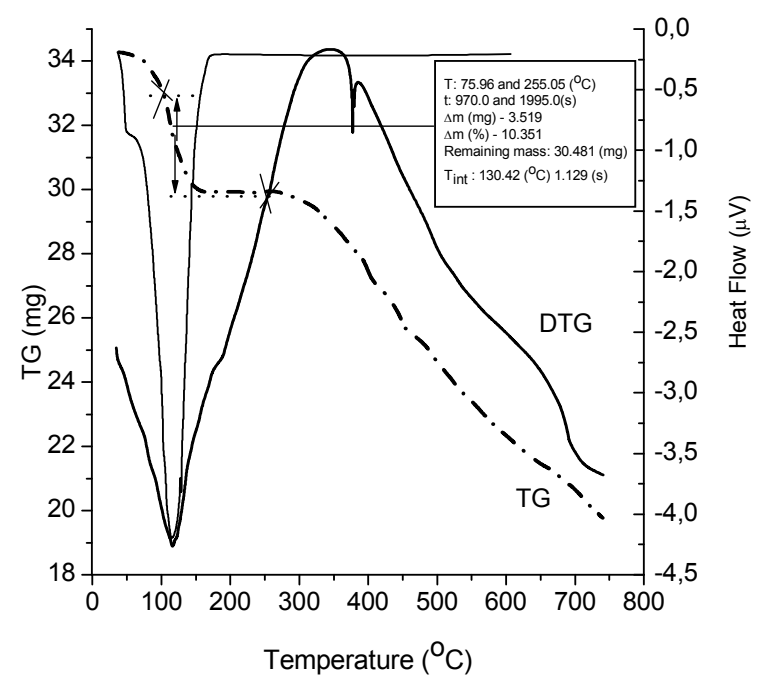

Fig. 2. TG and DTG curves for Angren brown coal

For Angren coal the thermogravimetric (TG) curve (Fig. 2) shows a peak that refers to the manifestation of endothermic processes at temperatures from 75 to $252{ }^{\circ} \mathrm{C}$. Simultaneously, the differential thermogravimetric (DTG) curve sharply deepens at these temperature parameters, which shows the maximum value of endothermic reactions, where evaporation of mainly structural water and light volatile organic fractions are occurred. The decrease in the coal mass is about $10.3 \%$. The evaporation curve does not change at the range of temperature from $252{ }^{\circ} \mathrm{C}$ to $300^{\circ} \mathrm{C}$, i.e. there is some stabilization of processes. After $300^{\circ} \mathrm{C}$ and up to $800{ }^{\circ} \mathrm{C}$, the TG curve gradually decreases and goes down. This process is manifested at the activation of coal, where decarbonisation processes take place (in the table material is marked as an ash content) with burning out of a primary carbon. This is the carbon in the composition of carbonates, which burns in the first place, then there is a partial burning of volatile aromatic compounds.

The maximum degree of decarbonisation can reach up to $45 \%$. Theoretically, at high temperatures, all carbon must burn out. Experiments in the heat treatment of granules of bentonite-coal mixtures in a muffle furnace at different temperature parameters demonstrate burning out of primary carbon and carbonates from 12.8 to $23.6 \%$ (Table 5). The stage of their burnup is called ash-contents. Addition of the bentonite as the solid carrier to the bentonitecoal composition prevented from full and maximum burn up of coal. The optimum 
parameters for decarbonisation are temperature of $750{ }^{\circ} \mathrm{C}$ and time of $45 \mathrm{~min}$, at which the degree of decarbonization amounts to 19 to $27.6 \%$. Then, studying the sorption capacity of the sorbents, it was found that, the main optimal ratio of bentonite:coal was $1: 2$ at the temperature of $950{ }^{\circ} \mathrm{C}$ for $45 \mathrm{~min}$, and the decarbonization degree of $19 \%$. Data of decarbonization and activation of bentonite- carbon granules in a muffle furnace at different temperature is given in Table 5, where the maximum of burning of composite granules with an increased content of coal, i.e. with the ratio $\mathrm{B}: \mathrm{C}=1: 3$ it reaches $22-23 \%$, whereas in the ratios $2: 1$ and $1: 1$ the burning degree is quite low, due the amount of bentonite dominates over the amount of coal.

Table 5. Decarbonization and activation of bentonite-carbon granules in a muffle furnace at different temperature

\begin{tabular}{|c|c|c|c|c|c|c|c|c|c|c|}
\hline \multirow[b]{2}{*}{$\mathbf{N}$} & \multirow[b]{2}{*}{$\begin{array}{c}\text { Ratio } \\
\text { B:C }\end{array}$} & \multicolumn{2}{|c|}{$\begin{array}{c}600{ }^{\circ} \mathrm{C} \\
\text { Time - } 60 \mathrm{~min} \\
\end{array}$} & \multicolumn{2}{|c|}{$\begin{array}{c}620{ }^{\circ} \mathrm{C}, \\
\text { Time }-80 \mathrm{~min} \\
\end{array}$} & \multicolumn{2}{|c|}{$\begin{array}{c}650{ }^{\circ} \mathrm{C}, \\
\text { Time }-30 \text { min }\end{array}$} & \multicolumn{2}{|c|}{$\begin{array}{c}750{ }^{\circ} \mathrm{C}, \\
\text { Time }-45 \mathrm{~min} \\
\end{array}$} & \multirow[b]{2}{*}{$\begin{array}{c}\text { Ash, av. } \\
\%\end{array}$} \\
\hline & & $\begin{array}{c}\text { Initial } \\
\text { mass } 150 \mathrm{~g}, \\
\text { remained, } \\
\mathrm{g}\end{array}$ & $\underset{\%}{\text { Ash, }}$ & $\begin{array}{c}\text { initial } \\
\text { mass } \\
150 \mathrm{~g}, \\
\text { remained, } \\
\mathrm{g}\end{array}$ & $\underset{\%}{\text { Ash, }}$ & $\begin{array}{c}\text { initial } \\
\text { mass } \\
100 \mathrm{~g}, \\
\text { remained, } \\
\mathrm{g}\end{array}$ & Ash, \% & $\begin{array}{c}\text { initial } \\
\text { mass } \\
100 \mathrm{~g}, \\
\text { remained, } \\
\mathrm{g}\end{array}$ & $\begin{array}{c}\text { Ash, } \\
\%\end{array}$ & \\
\hline 1 & $2: 1$ & 130.8 & 12.8 & 124.7 & 16.8 & 78.6 & 21.4 & 74.1 & 25.9 & 19.2 \\
\hline 2 & $1: 1$ & 120 & 20.8 & 120.4 & 19.7 & 80.8 & 19.2 & 79.4 & 20.6 & 20.0 \\
\hline 3 & $1: 2$ & 114.5 & 23.6 & 117.5 & 21.6 & 75.7 & 24.3 & 81.0 & 19.0 & 22.1 \\
\hline 4 & $1: 3$ & 124.6 & 17.0 & 127.5 & 15.0 & 76.5 & 23.5 & 72.4 & 27.6 & 20.7 \\
\hline 5 & $\begin{array}{c}1: 3 \\
\mathrm{CaO}\end{array}$ & 115.8 & 22.8 & 123.0 & 18.0 & 75.9 & 24.1 & 73.2 & 26.8 & 22.9 \\
\hline
\end{tabular}

As can be seen from Fig. 3 (TG curves), the decrease in the initial mass of bentonite occurs over a certain time with increasing temperature parameters (DTG curve). The parallel downward TG and DTG curves show the dominance of endothermic processes. The primary decomposition of bentonite begins at a temperature of $70{ }^{\circ} \mathrm{C}$, and ends at $300{ }^{\circ} \mathrm{C}$. During this period of time ( $35 \mathrm{~min})$, the weight loss is $45 \mathrm{mg}$ from $363.0 \mathrm{mg}$ or $11 \%$ of the total mass. The loss is due to absorbed structural water and other highly volatile impurities. In the second stage of decomposition at a temperature of $460{ }^{\circ} \mathrm{C}$, the remaining mass of $338 \mathrm{mg}$ decreases to $325 \mathrm{mg}$, or $3.8 \%$ of the initial mass. At this stage, the mass decreases due to the evaporation of carbonates, and other volatile impurities that can decompose at these temperatures. It took about $18 \mathrm{~min}$. Total, the decomposition of bentonite took about $58 \mathrm{~min}$, and the weight loss was $4 \%$. After this, the decomposition process stopped and on a solid carrier (bentonite), possibly stable metal oxides remained.

Thus, the combination of the TG and DTG curves of coal and bentonite are the same. Endothermic reactions (the first peak) with the primary evaporation of structural water and volatile organic substances occurred in the temperature ranges from 70 to $300{ }^{\circ} \mathrm{C}$. The second peak was noted mainly after $300^{\circ} \mathrm{C}$, where the coal burned completely, and stable metal oxides remained in the bentonite composition and in the clay carrier - bentonite. By the thermogravimetric analysis of coal and bentonite, optimal parameters of decarbonization were defined - at $600^{\circ} \mathrm{C}$ for $40 \mathrm{~min}$ and activation at $950{ }^{\circ} \mathrm{C}$ for $45 \mathrm{~min}$.

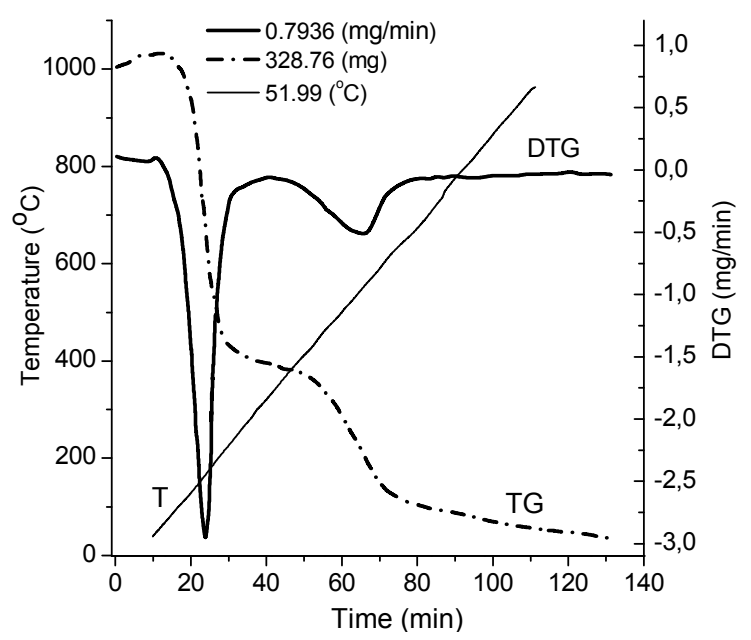

Fig. 3. TG and DTG curves for bentonite from the Navbahor deposit 
The main parameters for the quality control of the obtained granules are the determination of sorption capacity, strength and regeneration ability for further multiple applications.

At the present day, the soot, obtained after the pyrolysis stage of methane from shop No. 6 of Navoiyazot, is a waste of production. Such soot is released up to 1200 tons per a year. The soot obtained in this way is mainly carbon. Therefore, the use of carbon as a basis for producing activated carbons is relevant. TG curve of soot shows a splitting by an explosive way. The mass of the sample increases with the raise of temperature due to the conversion of organic carbon compounds during combustion. Herewith exothermic processes are noticed within the temperatures from 180 to $510^{\circ} \mathrm{C}$. Correspondingly, the maximum of the exothermic curves is observed with increasing of the sample mass (Fig. 4).

The beginning of endothermic processes is noted within the temperatures from 520 to $820^{\circ} \mathrm{C}$. The maximum reduction in the mass of soot occurs at a temperature of 830 to $980{ }^{\circ} \mathrm{C}$ and is $40 \%$. Thus, the optimum parameter for burning out organic compounds in the soot composition is a temperature range from 520 to $1080^{\circ} \mathrm{C}$, where the maximum carbon burning up to $75 \%$ is observed.

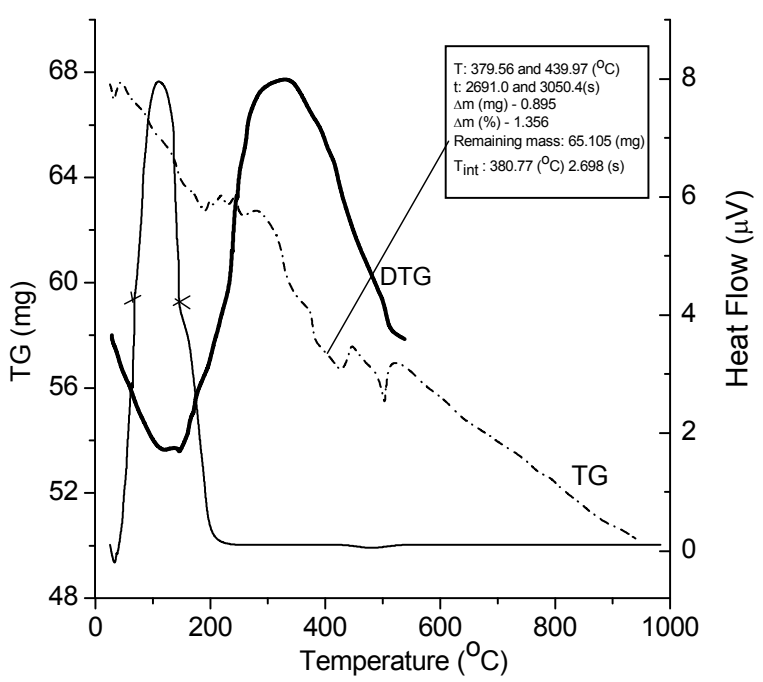

Fig. 4. TG and DTG curves for of soot after methane pyrolysis

In Fig. 5, according to A.D. Smirnova [23], the temperature parameters, at which burnout of various types of compounds occur are detailed.

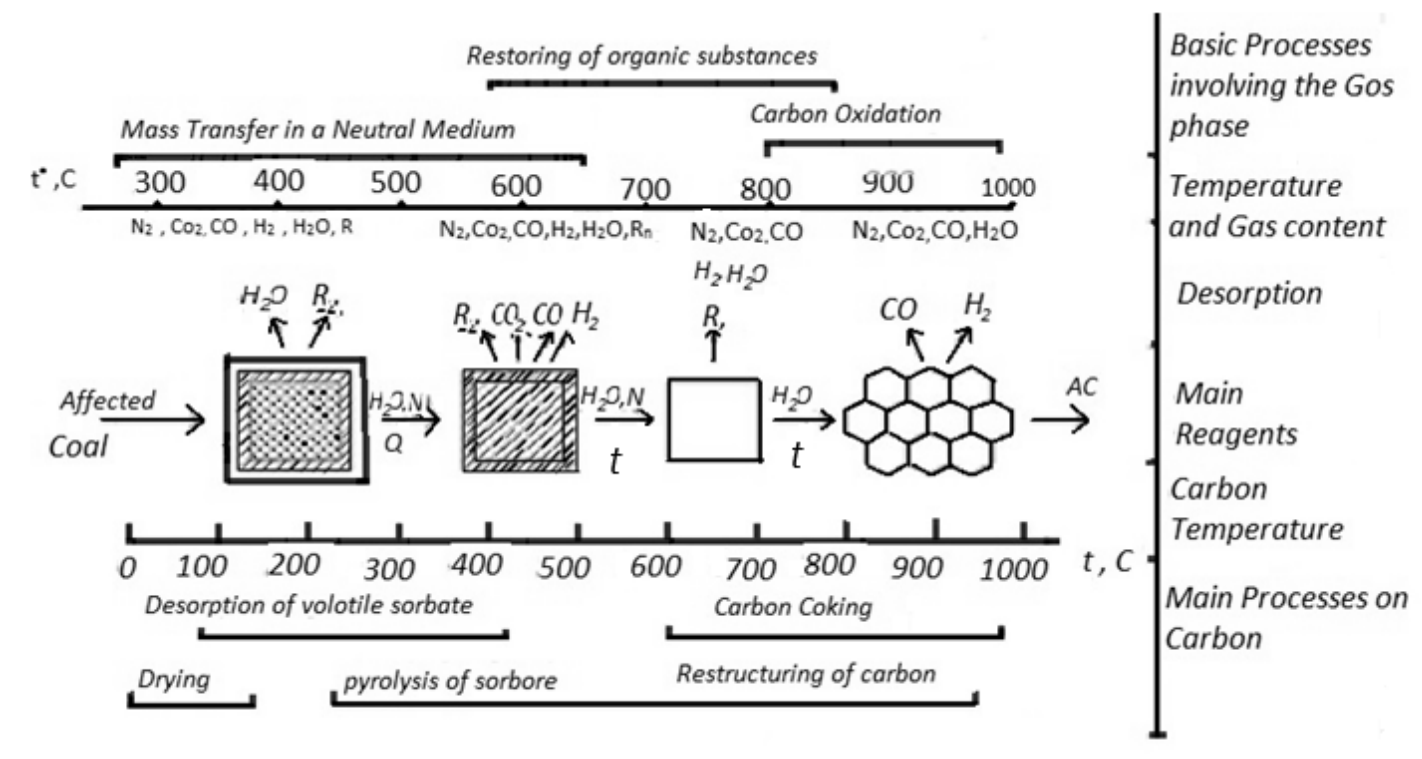

Fig. 5. Schematic diagram of thermal regeneration processes of active coals (according to Smirnova A.D.) [23]

Thus, in the temperature range from 100 to $200{ }^{\circ} \mathrm{C}$, mainly structured water evaporates, at temperatures from 400 to $500{ }^{\circ} \mathrm{C}$ - volatile compounds of nitrogen, carbon dioxide and carbon monoxide, and then burnout of aromatic compounds starts at temperatures from 800 to $1000^{\circ} \mathrm{C}$. Nonvolatile organic pollutants decompose for $1-2$ min when the coal is heated 
to $500-700{ }^{\circ} \mathrm{C}$. This process is more effective and faster in a neutral and weakly reducing medium and is limited by the rate of heating of the material. Increasing the temperature of the sorbent heating to $700-1000{ }^{\circ} \mathrm{C}$ promotes the restructuring of the secondary structure of carbon of sorbate, stabilizes its properties, which simplifies its reactivation, especially in cases of a sorbate with a complex variable composition. This phase of activated carbons treatment is also advisable to implement in a medium with a low reactivity. Otherwise, gasification of secondary carbon, starting at $650-700{ }^{\circ} \mathrm{C}$, should be completed in 3-5 min at a temperature of no higher than $1020-1070{ }^{\circ} \mathrm{C}$ in order to avoid excessive graphitization of coal. The stage of the sorbent treatment, which determines its basic properties, is reactivation, i.e. the formation of a new active surface by selective oxidation of the secondary carbon of the sorbate and part of the initial sorbent.

Thus, the results of the thermogravimetric analysis of the raw materials of coal, bentonite and soot are shown the practical possibility of using coal and bentonite as initial materials for the production of new sorbents. The situation with soot is somewhat different, since the maximum amount of technical carbon in its composition does not give the maximum amount of formed pores during the heat treatment because of the soot contains no aromatic compounds, the burning out of which contributes to the formation of pores.

\section{CONCLUSIONS}

Thus, in this paper the possibility of compatibility of the burning out parameters of two different types of compounds - Angren coal and bentonite from the Navbakhor deposit - is shown in order to obtain new hybrid types of sorbents that can be used for sewage treatment of industrial enterprises with their recycling usage in closed mode. The results of the thermogravimetric analysis of the raw materials of coal, bentonite and soot are shown the practical possibility of using coal and bentonite as an initial material for the production of new sorbents. The situation with soot is somewhat different, since the maximum amount of technical carbon in its composition does not give the maximum amount of formed pores during the heat treatment because of the soot contains no aromatic compounds, the burning out of which contributes to the formation of pores. Thermogravimetric analysis of soot after methane pyrolysis has shown that the maximum amount of carbon without the presence of a clearly formed crystalline lattice, which is noted in the composition of coal, does not allow obtaining a certain porosity of the material. The creation of a hybrid material based on bentonite and soot will make it possible to obtain a sorbent with less pronounced sorption properties than the bentonite-coal composite.

\title{
Вивчення та підбір вихідних матеріалів як можливих джерел для одержання сорбентів
}

\author{
І.А. Тагаєв, С.У. Турсунова, Л.С. Андрійко
}

Навоійський державний гірничий інститут пр. Галаба, 170, Навої, 210100, Узбекистан

Інститут хімії поверхні ім. О.О. Чуйка Національної академії наук України вул. Генерала Наумова, 17, Київ, 03164, Україна, andriykolyuda@gmail.com

У статті наведено відомості про підбір вихідних матеріалів на основі бентоніту, бурого вугілля $i$ технічної сажі для отримання сорбентів нового типу. Одержання нових ефективних вугільних сорбентів на основі місчевого Ангренського вугілля, дослідження їх колоїдно-хімічних і адсорбційних властивостей, а також пошук нових областей їх ефективного практичного застосування для очищення виробничих стоків хімічної та металургійної промисловості становлять великий науково-практичний інтерес $і$ є дуже актуальними. Створення сорбентів з такими властивостями пов'язано з великими витратами енергї̈, що реализується шляхом використання спеціального обладнання для термообробки матеріалу. Таким чином, 
мета дослідження полягала в тому, щьоб знайти способи не тільки знизити витрати на виробництво активованого вугілля з використанням місцевої сировини, а й повторно використовувати їх з наступною регенерацією. Для цьього були проведені попередні дослідження по визначенню різниці температур під час термічної декарбонізації $i$ активації вихідних матеріалів - Ангренського вугілля, сажі з иеху № 6 АT «Навоіазот» $i$ бентоніту з родовища Навбахор термогравіметричними методами. Виявлено, щзо основним оптимальним співвідношенням бентоніт/вугілля було 1/2 при температурі $950{ }^{\circ} \mathrm{C}$ протягом 45 хв, де ступінь декарбонізащії становила 19\%. Оптимальним параметром для вигоряння органічних сполук в композиті з сажею є діапазон температур від 520 до $1080^{\circ} \mathrm{C}$, де спостерігається максимальний викид вуглецю до $75 \%$. Підвищення температури нагрівання сорбенту до 700-1000 ${ }^{\circ} \mathrm{C}$ сприяє реструктуризаціi вторинної структури вуглецю, стабілізує його властивості, щчо спрощує його реактивацію, особливо у випадку сорбента зі складним змінним складом. Показана можливість сумісності параметрів вигоряння двох різних типів сполук - Ангренського вугілля $і$ бентоніту з родовища Навбахор - з метою одержання нових типів гібридних сорбентів, які можна використовувати для очищення стічних технологічних вод промислових підприємств з повторним їх використанням в замкнутому режимі.

Ключові слова: вугільні адсорбенти, Ангренське вугілля, сажа, бентоніт, термогравіметричний аналіз

\title{
Изучение и подбор исходных материалов как возможных источников для получения сорбентов
}

\author{
И.А. Тагаев, С.У. Турсунова, Л.С. Андрийко
}

Навоийский государственный горныий институт пр. Галаба, 170, Навои, 210100, Узбекистан

Институт химии поверхности им. А.А. Чуйка Наџиональной академии наук Украинь ул. Генерала Наумова, 17, Киев, 03164, Украина, andriykolyuda@gmail.com

В статье приведень сведения о подборе исходных материалов на основе бентонита, бурого угля и технической сажи для получения сорбентов нового типа. Получение новых эффективных угольных сорбентов на основе местных ангренских углей, исследование их коллоидно-химических и адсорбционных свойств, а также изыскание новых областей их эффективного практического применения для очистки производственных стоков химической и металлургической промышиленности представляют большой научно-практический интерес и являются весьма актуальными. Создание сорбентов с такими свойствами связано с большими затратами энергии, которые выполняются с использованием специиального оборудования для термообработки материала. Таким образом, иель исследования заключалась в том, чтобы найти способы не только снизить затраты на производство активированных углей с вовлечением материалов на основе местного сырья, но и повторно использовать их с последующей регенеращией. Для этого предварительные исследования определения разности температур во время термической декарбонизации и активации исходных материалов - ангренского угля, сажи из цеха № 6 АО «Навоиазот» $и$ бентонита с месторождения Навбахор были проведены термогравиметрическими методами. Обнаружено, что основным оптимальным соотночением бентонит/уголь было $1 / 2$ при температуре $950^{\circ} \mathrm{C}$ в течение 45 мин, где степень декарбонизащии составляла 19\%. Оптимальным параметром для выгорания органических соединений в композите с сажей является диапазон температур от 520 до $1080{ }^{\circ} \mathrm{C}$, где наблюдается максимальный выброс углерода до $75 \%$. Повышение температурь нагрева сорбента до 700-1000 ${ }^{\circ} \mathrm{C}$ способствует реструктуризации вторичной структуры углерода, стабилизирует его свойства, что упрощает его реактивачию, особенно в случае сорбента со сложным переменным составом. Показана возможность совместимости параметров выгорания двух разньх типов соединений ангренского угля и бентонита с месторождения Навбахор - с иелью получения новых типов гибридных сорбентов, которые можно использовать для очистки сточных технологических вод промышленных предприятий с повторным их использованием в замкнутом режиме.

Ключевые слова: угольные адсорбенты, Ангренский бурый уголь, сажа, бентонит, термогравиметрический анализ 


\section{REFERENCES}

1. Ochilov G.M. Ph.D (Chem.) Thesis. (Tashkent, 2011) [in Russian].

2. Gorbaty M.L., Larsen J.W., Wender I. Coal Sience. (Academic Press: Elsevier, 1982).

3. Marsh H., Rodriguez-Reiniso F. Activated carbon. (Amsterdam: Elsevier, 2006).

4. https://www.eia.gov/todayinenergy/detail.php?id=34992

5. https://www.ceicdata.com/en/indicator/uzbekistan/coal-consumption

6. Abdugafforov K. Master's Ph.D (Chem.) Thesis. (Togliatti, 2016). [in Russian].

7. Evans M.J.B., Halliop E., MacDonald J.A.F. The production of chemically activated carbon. Carbon. 1999. 37(2): 269.

8. Islamov S., Stepanov S., Sergeeva Yu. The brown coal sorbent - for sewage treatment. Ecology of production from the first person. 2015. 1(17):176. [in Russian].

9. Urazov T.S., Bychkov A.L., Lomovsky O.I. Mechanochemical modification of the structure of humic acids of brown coal for obtaining heavy metal sorbent. J. Appl. Chem. 2016. 87(5): 664. [in Russian].

10. Chesnokov N.V., Mikova N.M., Ivanov I.P., Kuznetsov B.N. Synthesis of carbon sorbents by chemical modificationof fossil coals and plant biomass. Journal of Siberian Federal University. Chemistry 1. 2014. 7: 42. [in Russian].

11. Domracheva V.A., Shiirav G. Carbon sorbents from Mongolian brown coals. Proceedings of the Mongolian Academy of Sciences. 2012. 52(4): 20. [in Russian].

12. Budaeva A.D., Zoltaev E.V. Composition and properties of sorbents obtained from oxidized brown coals of the Gusinoozersky deposit. Mining informational and analitical bulleti (Scientific And Technical Journal). 2012. 2: 122. [in Russian].

13. Bansal R.C., Goyal M. Activated carbon adsorption. (Boca Raton: Taylor and Francis group, 2005).

14. http://www.silcarbon.eu/englisch/products/activated-carbon/index.html

15. http://www.cabotcorp.com/solutions/products-plus/activated-carbon

16. https://trayal.rs/en/products/protective-devices/activated-carbon

17. Almyashev V.I., Gusarov V.V. Thermal methods of analysis. Tutorial. (St. Petersburg, 1999). [in Russian].

18. Commercial offer of LLC "Bentonit". http://bentonite.uz/products.asp.htm

19. Interstate Standard (25543-888). Brow coal, coal and anthracite. Classification by genetic and technological parametershttp://docs.cntd.ru/document/gost-25543-88

20. Zhang J., Terrones M., Park Ch.R., Mukherjee R., Monthioux M., Koratkar N., Kim Y.S., Hurt R., Frackowiak E., Enoki T., Chen Y., Chen Y., Bianco A. Carbon science in 2016: Status, challenges and perspectives. Carbon. 2016. 98: 708.

21. Menéndez-Díaza J. A., Martín-Gullónb I. Types of carbon adsorbents and their production. Activated carbon surfaces in environmental remediation (Interface science and technology series, 7). (ELSEVIER, 2006).

22. Gun'ko V.M., Zaulychnyy Ya.V., Ilkiv B.I., Zarko V.I. Textural and electronic characteristics of mechanochemically activated composites with nanosilica and activated carbon. Appl. Surf. Sci. 2011. 258(3): 1115.

23. Smirnova A.D. Sorption Purification of Water. (Leningrad: Chemistry,1982). [in Russian]. 